\title{
Epidemiological evaluation of hepatic trauma victims undergoing surgery
}

\author{
Avaliação epidemiológica de vítimas de trauma hepático submetidas a \\ tratamento cirúrgico
}

Mitre Kalll, RCBC-ES'; IsaAc Massaud Amim Amaral ${ }^{2}$

\author{
A $B$ S S T T R A C C T
}

\begin{abstract}
Objective: to evaluate the epidemiological variables and diagnostic and therapeutic modalities related to hepatic trauma patients undergoing laparotomy in a public referral hospital in the metropolitan region of Vitória-ES. Methods: we conducted a retrospective study, reviewing charts of trauma patients with liver injuries, whether isolated or in association with other organs, who underwent exploratory laparotomy, from January 2011 to December 2013. Results: We studied 392 patients, 107 of these with liver injury. The male: female ratio was $6.6: 1$ and the mean age was 30.12 years. Penetrating liver trauma occurred in $78.5 \%$ of patients, mostly with firearms. Associated injuries occurred in $86 \%$ of cases and intra-abdominal injuries were more common in penetrating trauma $(p<0.01)$. The most commonly used operative technique was hepatorrhaphy and damage control surgery was applied in $6.5 \%$ of patients. The average amounts of blood products used were 6.07 units of packed red blood cells and 3.01 units of fresh frozen plasma. The incidence of postoperative complications was $29.9 \%$, the most frequent being infectious, including pneumonia, peritonitis and intra-abdominal abscess. The survival rate of patients suffering from blunt trauma was $60 \%$, and penetrating trauma, $87.5 \%(p<0.05)$. Conclusion: despite technological advances in diagnosis and treatment, mortality rates in liver trauma remain high, especially in patients suffering from blunt trauma in relation to penetrating one.
\end{abstract}

Key words: Liver. Abdominal Injuries. Wounds and Injuries. Firearms. Accidents, Traffic.

\section{INTRODUCTION}

Trauma is a public health problem of great magnitude in Brazil. It is one of the leading causes of death today, due to the increase in urban violence and the technological advancement of the automotive industry, which enabled the production of increased power vehicles ${ }^{1,2}$.

Abdominal trauma can be classified into two distinct types: penetrating or blunt. Blunt trauma is usually due to accidents involving motor vehicles, falls, explosions and sports injuries. Penetrating trauma, on its turn, can be caused by stabbing or gunshot projectiles ${ }^{3}$.

The most commonly affected organs in the blunt abdominal trauma are the spleen (40 to 55\%), liver (35 to $45 \%$ ) and small intestine (5 to 10\%). The injuries caused in penetrating abdominal trauma normally affect the liver $(40 \%)$, small intestine (30\%), the diaphragm (20\%) and colon (15\%). As for the injuries caused by firearm projectiles, they typically affect the small intestine (50\%), colon (40\%), liver (30\%) and abdominal vessels $(25 \%)^{1,4}$.

The high rates of liver injury are justified by its size and anatomical position ${ }^{5.6}$. The right lobe of the liver, being the portion of the bulkier hepatic parenchyma, is the most affected region in abdominal injuries ${ }^{7}$.

This study aims to assess the epidemiological variables of, and the diagnostic and therapeutic modalities applied to, patients submitted to surgical treatment of liver trauma at a referral hospital for trauma.

\section{METHODS}

We conducted a retrospective review of medical records of patients undergoing laparotomy in the period from January 2011 to December 2013, at the Hospital Estadual São Lucas, a referral center for trauma, located in the Metropolitan Region of Vitória-ES.

We included trauma patients with liver injury, isolated or in association with other intra or extra-abdominal organs. We excluded surgical re-approaches in patients operated on in other services and subsequently transferred to our hospital. The sample therefore comprised 107 patients undergoing surgery for hepatic injury during this period.

1. Departamento de Clínica Cirúrgica - Escola Superior de Ciências da Santa Casa de Misericórdia de Vitória - EMESCAM; 2. Escola Superior de Ciências da Santa Casa de Misericórdia de Vitória - EMESCAM. 
The variables analyzed were: age, gender, date and time of admission, the first operation time, length of stay, mechanism of injury, the presence of associated intra or extra-abdominal lesions, surgical technique, the intraoperative need for blood products, need for peri-hepatic drainage, postoperative complications and mortality.

The collected data were tabulated in electronic spreadsheets and statistical analyzes were performed according to Levine et al., at $2012^{8}$. We carried out a descriptive analysis of the categorical variables, expressed in absolute numbers and percentages, and the continuous ones as position measurements. To compare the trauma mechanisms in relation to the categorical variables, we used the chi-square test. We considered a $p$ value $<0.05$ as statistically significant.

This study was approved by the Ethics in Research Committee of the Santa Casa de Misericórdia de Vitória EMESCAM, on 30 of April 2014, under number 632.212.

\section{RESULTS}

During the study period, from January 2011 to December 2013, 392 patients underwent laparotomy, 107 of them sustaining liver injury. Of these, 93 were male $(86.9 \%)$ and 14 female (13.1\%). The mean age of patients suffering liver trauma was 30.12 years, ranging from 14 to 72 (median 28), and $83.2 \%$ were in the first four decades of life.

As for the mechanism of injury, the most common was penetrating trauma, which occurred in 84 patients (78.5\%). Of these, gunshot wounds (GW) accounted for 72 cases $(85.7 \%)$ and stab wounds (SW), for 12 cases (14.3\%). Blunt trauma occurred in 23 patients (21.5\%), whose origins were 12 motorcycle accidents $(52.2 \%)$, six car accidents $(26.1 \%)$, two falls from a height $(8.7 \%)$, running over in two (8.7\%) and unidentified in one (4.3\%).

Considering the anatomical site of liver injury, the right lobe was the most affected (46.73\%), followed by the left one (25.23\%) (Table 1). The caudate lobe was less affected, only in one case (0.93\%). Simultaneous injury of right and left lobes or the right and caudate lobes occurred in $5.61 \%$ and $0.93 \%$ of patients, respectively.

We found associated intra (Table 2) and extraabdominal (Table 3) lesions in 92 patients (86\%). Associated Intra-abdominal lesions occurred in 67 patients (62.6\%), the most damaged organs being the diaphragm, colon and stomach. Concomitant extra-abdominal lesions were found in 77 patients $(72 \%)$, mostly in the chest.

As for the associated extra-abdominal lesions (Table 3), there was a higher incidence of head injury associated with blunt trauma (30\% of cases) when compared with penetrating trauma (10.9\% of cases).

The days of the week with more liver trauma victims were Sunday (25.2\%), Wednesday (16.8\%) and Saturday (15.9\%) (Table 4). The days when with less victims were Monday (14\%), Friday (10.3\%), Thursday (9.3\%) and Tuesday (8.4\%).

The time between hospital admission and the first surgery was less than two hours in $48.8 \%$, between two and four hours in $17.9 \%$ patients and more than four hours in 33.3\%. The average hospitalization time for patients with blunt trauma was 13.96 days, and for patients with penetrating trauma, 12.23 days.

Regarding the surgical technique used to control liver bleeding, the most used was hepatorrhaphy (80.37\%) (Table 5). Cauterization of the liver injury has been reported in four patients (3.74\%), being a single and sufficient measure to stop bleeding in two of these patients. It was also described the use of topical hemostatic agents in two cases (1.87\%) and omentum transposition in only one case $(0.93 \%)$. In 12 patients $(11.21 \%)$ no measures of hemostasis were necessary, since the liver injury showed no active bleeding. Segmentectomy was performed in two patients $(1.87 \%)$ and only one $(0.93 \%)$ required left hepatectomy. Damage control surgery was performed in seven patients (6.54\%). Eighteen patients (16.82\%) needed further surgical intervention, mostly to withdraw textiles from the peritoneal cavity. Laparotomy was not therapeutic in four patients (3.74\%).

Table 1 - Anatomical liver lobes affected in patients sustaining liver trauma.

\begin{tabular}{lcr}
\hline Hepatic lobe & Frequency & $\%$ \\
\hline Right & 50 & 46.73 \\
Left & 27 & 25.23 \\
Caudate & 1 & 0.93 \\
Right and left & 6 & 5.61 \\
Right and caudate & 1 & 0.93 \\
Not identified & 22 & 20.56 \\
Total & 107 & 100.00 \\
\hline
\end{tabular}

Source: Medical records of Hospital Estadual São Lucas (January 2011 to December 2013).

Table 2 - Associated intra-abdominal lesions in patients sustaining liver trauma.

\begin{tabular}{lcc}
\hline Injured organ & Frequency & $\%$ \\
\hline Diaphragm & 30 & 20.27 \\
Colon & 26 & 17.57 \\
Stomach & 25 & 16.89 \\
Kidney & 17 & 11.49 \\
Small intestine & 17 & 11.49 \\
Spleen & 10 & 6.76 \\
Extrahepatic biliary tree & 9 & 6.08 \\
Great vessels & 8 & 5.4 \\
Pancreas & 6 & 4.05 \\
TOTAL & 148 & 100.00 \\
\hline
\end{tabular}

Source: Medical records of Hospital Estadual São Lucas (January 2011 to December 2013). 
Table 3 - Associated extra-abdominal lesions in patients sustaining liver trauma.

\begin{tabular}{lcr}
\hline Injured region & Frequency & \multicolumn{1}{c}{$\%$} \\
\hline Chest & 64 & 54.7 \\
Limbs & 37 & 31.62 \\
Head & 13 & 11.11 \\
Neck & 3 & 2.56 \\
Total & 117 & 100.00 \\
\hline
\end{tabular}

Source: Medical records of Hospital Estadual São Lucas (January 2011 to December 2013).

Table 4 - Days of the week on which medical care was provided to patients sustaining liver trauma.

\begin{tabular}{lcr}
\hline Weekday & Frequency & $\%$ \\
\hline Sunday & 27 & 25.2 \\
Monday & 15 & 14 \\
Tuesday & 9 & 8.4 \\
Wednesday & 18 & 16.8 \\
Thursday & 10 & 9.3 \\
Friday & 11 & 10.3 \\
Saturday & 17 & 15.9 \\
\hline
\end{tabular}

Source: Medical records of Hospital Estadual São Lucas (January 2011 to December 2013).

Twenty-eight patients required blood products transfusion during surgery (26.2\%) and the average amount of blood products used was 6.07 units of packed red blodd cells and 3.01 fresh plasma units. Perihepatic drains were placed in 27 cases (25.2\%), a Penrose drain being the most commonly used $(n=15)$.

The incidence of postoperative complications was $29.9 \%$, and the most frequent were infectious, including pneumonia, peritonitis and intra-abdominal abscess, which represented $73.9 \%$ of complications. Hemobilia occurred in one patient, who was treated with hepatic artery embolization.

The survival rates were $60 \%$ in patients with blunt trauma, and in patients with penetrating trauma, $87.5 \%$ $(p<0.05)$ (Table 6). The mortality rate was $17.8 \%(n=19)$, the most common causes of death being hemorrhagic shock, responsible for ten deaths (52.6\%), and septic shock, amounting to four deaths (21\%).

\section{DISCUSSION}

Hepatic trauma occurred more frequently in males $(86.9 \%)$ in the first four decades of life $(83.2 \%)$. These results are similar to those reported by many researchers ${ }^{2,3,9,10}$. The highest incidence of trauma in young adult males is associated with increased risk behavior due to exposure to alcohol and illicit drugs ${ }^{10}$.

Due to the increase of traffic accidents and violence in Brazil, the proportion of trauma admissions has gradually increased and hence the proportion of government spending. Likewise, hospital costs are directly proportional to the length of hospital stay ${ }^{10}$. In this study, the average hospitalization time for patients with blunt trauma was 13.96 days, and for patients with penetrating trauma, 12.23 days, agreeing with the average found in the literature ${ }^{9}$.

Lima et al. studied the epidemiology of abdominal trauma undergoing laparotomy and, as well as in our work, observed that there was a higher prevalence of trauma on weekends ${ }^{10}$.

Mortality in hepatic trauma in most studies is close to $20 \%$, considering all cases admitted to hospital ${ }^{9}$. The mortality rate in this study was $17.8 \%$. Of the eleven deaths from penetrating trauma, ten were the result of gunshot wounds.

Other intra-abdominal injuries concomitant with liver lesions were more common in penetrating trauma $(p<0.01)$, as shown in table 6 . In penetrating abdo-

Table 5 - Surgical techniques applied in the treatment of patients sustaining liver trauma.

\begin{tabular}{lcc}
\hline Technique* & Patients & $\%$ \\
\hline Hepatorrhaphy & 86 & 80.37 \\
Segmentectomy & 2 & 1.87 \\
Left hepatectomy & 1 & 0.93 \\
Electrocauterization & 4 & 3.74 \\
Topical hemostatic agents & 2 & 1.87 \\
Epiploplasty & 1 & 0.93 \\
Damage Control & 7 & 6.54 \\
No action (liver damage with no active bleeding) & 12 & 11.21 \\
Nontherapeutic laparotomy & 4 & 3.74
\end{tabular}

Source: Medical records of Hospital Estadual São Lucas (January 2011 to December 2013).

* In some patients, more than one approach was performed 
Table 6 - Associated intra-abdominal lesions and survival rate in blunt and penetrating trauma in patients sustaining liver trauma.

\begin{tabular}{lccc}
\hline & Blunt & trauma $(\mathrm{n}=20)$ & Penetrating trauma $(\mathrm{n}=64)$ \\
\hline Associated intra-abdominal lesions* & 6 & $(30 \%)$ & $46(71.9 \%)$ \\
Survival rate ** & 12 & $(60 \%)$ & $56(87.5 \%)$ \\
\hline
\end{tabular}

Source: Medical records of Hospital Estadual São Lucas (January 2011 to December 2013).

* The result of the chi-square test indicated rejection of the null hypothesis at a significance level of $<1 \%(p<0.01)$.

** The result of the chi-square test indicated rejection of the null hypothesis at a significance level of $<5 \%(p<0.05)$.

minal trauma, the injuries of large intra-abdominal vessels stand out ${ }^{11}$. In this study, all eight injuries of large intraabdominal vessels were caused by penetrating trauma, seven of them by firearms. The vessels involved were: inferior vena cava, middle hepatic vein, splenic artery, right common iliac artery and vein, superior mesenteric vein and artery.

Hepatorrhaphy was the most used surgical technique to control liver bleeding. Other techniques include direct ligation of bleeding vessels, cauterization, the use of topical hemostatic agents, partial liver resection and hepatic artery ligation. In selected cases, refractory bleeding can be controlled with liver packing, the damage control surgery ${ }^{6}$.

The damage control surgery was performed in seven cases (6.54\%) and patient survival was 100\%, which confirms damage control as a measure which increases the survival rate of seriously injured patients who face the so-called triad of death - hypothermia, coagulopathy and metabolic acidosis ${ }^{6,11,12}$.

Research on the surgical treatment of hepatic injury began to grow in the early twentieth century. The maneuver of Pringle and liver packing technique were described in 1908, giving rise to the concept of damage control surgery ${ }^{11,13}$. Liver packing became a common practice a few years later, during the two Great World Wars. At that time, mortality related to hepatic trauma was $60 \%{ }^{13,14}$

After World War II, the mortality of liver trauma decreased due to increased experience in the repair of injuries. This led to the abandonment of surgery for damage control, which at the time was associated with a high incidence of late onset sepsis and rebleeding after packing removal. From the 70s on, surgery for damage control regained its importance in selected patients ${ }^{14}$.

Until the early 90s, surgical treatment was the standard treatment of liver injury ${ }^{15}$. Since then, the diagnostic and therapeutic approach to abdominal trauma victim suffered intense changes ${ }^{6}$. Initially, it was found that most liver injuries spontaneously stopped bleeding ${ }^{6.16}$. In 1908, Pringle had suggested that minor liver damage occasionally could heal without surgical intervention ${ }^{13}$. However, little had been published about non-operative treatment until the 80 's and the surgeons were resistant to conservative treatment, especially in blunt trauma ${ }^{16,17}$.
This resistance resulted primarily from three factors: the belief that liver bleeding would not cease unless surgically controlled; the concern that the lack of bile drainage would result in biliary fistulas and infectious complications; and the concern about associated lesions in face of a positive peritoneal lavage ${ }^{17}$.

With technological advances in imaging and greater accessibility to computed tomography and FAST (Focused Assessment with Sonography for Trauma), conservative treatment has become possible for patients with hemodynamically stable hepatic trauma ${ }^{15,18}$, which contributed to reduce unnecessary laparotomy ${ }^{7,12,18-21}$. Thus, there is a tendency to avoid routine laparotomy, especially for patients with hepatic trauma who are hemodynamically stable and displsy signs of peritonitis ${ }^{19}$.

Besides the advantage of avoiding the morbidity of an unnecessary laparotomy ${ }^{15}$, conservative treatment has shown other advantages over the surgical one, such as lower complication rates, less need for blood products transfusions, shorter hospital stay, especially in Intensive Care Units, and lower mortality ${ }^{15,16,19,21 .}$.

FAST is an exam with high sensitivity for the diagnosis of hemoperitoneum in hemodynamically unstable patients, as well as to identify liver damage ${ }^{18.22}$. A major advantage of this test is that it can be done at the bedside, without the need to move the patient from the emergency room ${ }^{18}$.

On the other hand, when the patient is hemodynamically stable, triple contrast $\mathrm{CT}$ is the method of choice in patients with blunt abdominal trauma. Computed tomography allows to determine the extent of liver damage, document the presence of active bleeding and detect associated lesions ${ }^{22}$. It is very useful in defining the severity of liver injury and the decision of conservative treatment ${ }^{18}$.

The diagnostic peritoneal lavage (PL) is a useful test for the diagnosis of hemoperitoneum when the patient is hemodynamically unstable and has sensory changes, and when there's no ultrasonography and CT available in the institution. Therefore, the PL can be replaced by ultrasound and, in more stable patients, $C^{22}$

According to Zago et al., there has been a decrease in the incidence of penetrating trauma and increased incidence of blunt trauma in Brazil in recent years ${ }^{9}$. 
However, this study found a higher prevalence of penetrating trauma (76.2\%). This discrepancy can be explained by the fact that our study only examined the operated patients, and patients treated conservatively - most victims of blunt trauma - were not counted. It is noteworthy that the conservative treatment of hepatic trauma in patients with hemodynamic stability has become standard in most trauma centers ${ }^{16,22}$.

In this study, the right lobe of the liver was the most affected, which was also demonstrated by Talving et al. ${ }^{23}$. According to Romano et al., the right lobe is the most affected because it is the most voluminous part of the hepatic parenchyma ${ }^{7}$. Associated lesions were found in 72 patients (85.7\%). The high number of associated injuries is a major challenge for the management of patients because their presence hinders the decision of conservative treatment ${ }^{2,3}$ and often determines the evolution of the patient ${ }^{12}$.
We observed a low incidence of postoperative complications (29.9\%). This complication rate obtained is below the parameters found in some studies on the epidemiology of liver trauma, the rates varying from 36 to $38.9 \% 9,24$.

We found (Table 6) that the mortality rate for patients with hepatic injury was greater for blunt trauma $(40 \%)$ than for penetrating one $(12.5 \%)$, possibly due to the higher rates of cranial injuries associated with blunt trauma. Zago et al. found similar results, with a mortality rate of $26.5 \%$ for blunt trauma and $15.8 \%$ for the penetrating one ${ }^{9}$.

Despite technological advances in diagnosis and treatment, and the systematization of care for polytrauma proposed by the Advanced Trauma Life Support (ATLS®), morbidity and mortality rates in liver trauma remain high $7,24,25$. Therefore, liver trauma is a serious public health problem with significant social and economic costs, especially since it affects people of working age.

\title{
R E S U M O
}

\begin{abstract}
Objetivo: avaliar as variáveis epidemiológicas e as modalidades diagnósticas e terapêuticas relacionadas ao trauma hepático de pacientes submetidos à laparotomia exploradora em um hospital público de referência da Região Metropolitana de Vitória-ES. Métodos: estudo retrospectivo de revisão de prontuários dos pacientes vítimas de trauma com lesão hepática isolada ou associada a outros órgãos, submetidos à laparotomia exploradora, no período de janeiro de 2011 a dezembro de 2013. Resultados: foram estudados 392 pacientes submetidos à laparotomia, dos quais 107 com lesões hepáticas. A relação masculino:feminino foi 6,6:1 e a média de idade dos pacientes foi 30,12 anos. O trauma hepático penetrante ocorreu em $78,5 \%$ dos pacientes, principalmente por arma de fogo. Lesões associadas ocorreram em $86 \%$ dos casos e as lesões intra-abdominais foram mais comuns no trauma penetrante $(p<0,01)$. A técnica operatória mais utilizada foi a hepatorrafia, e a cirurgia para controle de danos foi feita em $6,5 \%$ dos pacientes. A quantidade média de hemoderivados utilizados foi 6,07 unidades de hemoconcentrado e 3,01 unidades de plasma fresco. A incidência de complicações pós-operatórias foi $29,9 \%$, e as mais frequentes foram as infecciosas, incluindo pneumonia, peritonite e abscesso intra-abdominal. A taxa de sobrevida dos pacientes acometidos de trauma contuso foi $60 \%$ e de trauma penetrante, $87,5 \%(p<0,05)$. Conclusão: apesar dos avanços tecnológicos de diagnósticos e tratamentos, as taxas de morbimortalidade nos traumas hepáticos permanecem elevadas, especialmente nos pacientes acometidos de trauma hepático contuso em relação ao trauma penetrante.
\end{abstract}

Descritores: Fígado. Traumatismos Abdominais. Ferimentos e Lesões. Armas de Fogo. Acidentes de Trânsito.

\section{REFERENCES}

1. Pereira Júnior GA, Lovato WJ, Carvalho JB, Horta MFV. Abordagem geral trauma abdominal. Medicina. 2007;40(4): 518-30.

2. Stalhschmidt CMM, Formighieri B, Marcon DM, Takejima AL, Soares LGS. Trauma hepático: epidemiologia de cinco anos em um serviço de emergência. Rev Col Bras Cir. 2008;35(4):225-8.

3. Ribas-Filho JM, Malafaia O, Fouani MM, Justen MS, Pedri LE, Silva LMA, et al. Trauma abdominal: estudo das lesões mais frequentes do sistema digestório e suas causas. $A B C D$, arq bras cir dig. 2008;21(4):170-4.

4. ATLS. Trauma abdominal e pélvico. In: Suporte avançado de vida no trauma para médicos: manual do curso de alunos. $8^{\text {a }}$ ed. Chicago: American College of surgeons; 2009.

5. Reed RL 2nd, Merrell RC, Meyers WC, Fischer RP. Continuing evolution in the approach to severe liver trauma. Ann Surg. 1992;216(5):524-38.

6. Smaniotto B, Bahten LCV, Nogueira Filho DC, Tano AL, Thomaz Júnior L, Fayad O. Trauma hepático: análise do tratamento com balão intra-hepático em um hospital universitário de Curitiba. Rev Col Bras Cir. 2009;36(3):217-22.

7. Romano L, Giovine S, Guidi G, Tortora G, Cinque T, Romano S. Hepatic trauma: CT findings and considerations based on our experience in emergency diagnostic imaging. Eur J Radiol. 2004;50(1):59-66.

8. Levine DM, Berenson ML, Stephan D. Estatística: teoria e aplicações usando Microsoft Excel em português. $\sigma^{\text {a }}$ ed. Rio de Janeiro: LTC; 2012.

9. Zago TM, Pereira BM, Nascimento B, Alves MSC, Calderan TRA, Fraga GP. Trauma hepático: uma experiência de 21 anos. Rev Col Bras Cir. 2013;40(4):318-22.

10. Lima SO, Cabral FLD, Pinto Neto AF, Mesquita FNB, Feitosa MFG, Santana VR. Epidemiological evalution of abdominal trauma victims submitted to surgical treatment. Rev Col Bras Cir. 2012;39(4):302-6.

11. Stalhschmidt CMM, Formighieri B, Lubachevski FL. Controle de danos no trauma abdominal e lesões associadas: experiência de cinco anos em um serviço de emergência. Rev Col Bras Cir. 2006;33(4):215-9. 
12. César A, Duránd L, Delgado BV. Trauma hepático. Rev gastroentero Peru. 2001;21(2):115-22.

13. Pringle JH. V. Notes on the arrest of hepatic hemorrhage due to trauma. Ann Surg. 1908;48(4):541-9.

14. Hindosh LN. Evaluation of patients with liver injuries treated by perihepatic gauze packing. Al-Kindy Col Med J. 2008;4(2):45-50.

15. David Richardson J, Franklin GA, Lukan JK, Carrillo EH, Spain DA Miller FB, et al. Evolution in the management of hepatic trauma: a 25-year perspective. Ann Surg. 2000;232(3)324-30.

16. Croce MA, Fabian TC, Menke PG, Waddle-Smith L, Minard G, Kudsk KA, et al. Nonoperative management of blunt hepatic trau$\mathrm{ma}$ is the treatment of choice for hemodynamically stable patients. Ann Surg. 1995;221(6):744-53; discussion 753-5.

17. Malhotra AK, Fabian TC, Croce MA, Gavin TJ, Kudsk KA, Minard $G$, et al. Blunt hepatic injury: a paradigm shift from operative to nonoperative management in the 1990s. Ann Surg. 2000;231(6):804-13

18. Radwan MM, Abu-Zidan FM. Focussed Assessment Sonograph Trauma (FAST) and CT scan in blunt abdominal trauma: surgeon's perspective. Afr Health Sci. 2006;6(3):187-90.

19. Zago TM, Pereira BM, Calderan TRA, Hirano ES, Rizoli S, Fraga GP. Trauma hepático contuso: comparação entre o tratamento cirúrgico e o não operatório. Rev Col Bras Cir. 2012;39(4):307-13.

20. Butt MU, Zacharias N, Velmahos GC. Penetrating abdominal injuries: management controversies. Scand J Trauma Resusc Emerg Med. 2009;17:19.
21. Schroeppel TJ, Croce MA. Diagnosis and management of blunt abdominal solid organ injury. Curr Opin Crit Care. 2007;13(4):399404.

22. Stracieri LDS, Scarpelini S. Hepatic injury. Acta Cir Bras. 2006;21 Suppl 1:85-8.

23. Talving $P$, Beckman $M$, Häggmark $T$, Iselius L. Epidemilogy of liver injuries. Scand J Surg. 2003;92(3):192-4.

24. Velho AV, Ostermann RAB, Dacanal FM, Bayer LR. Análise dos fatores preditivos de complicações após trauma hepático penetrante. Rev Col Bras Cir. 1999;26(2):97-101.

25. Hurtuk M, Reed RL 2nd, Esposito TJ, Davis KA, Luchette FA. Trauma surgeons parctice what they preach: the NTDB story on solid organ injury management. J Trauma. 2006;61(2):243-54.

Received: 13/08/2015

Accepted for publication: 30/11/2015

Conflict of interest: none.

Funding source: Bolsa de PIBIC do Fundo de Apoio à Ciência e Tecnologia - Facitec.

\section{Mailing address:}

Isaac Massaud Amim Amaral

E-mail: isaac_amim@hotmail.com 